\title{
Curriculum interfaces at the undergraduation for the effectiveness of human rights education
}

\author{
Interfaces curriculares na graduação para efetivação da \\ educação em direitos humanos
}

\section{Ana Maria Eyng, Marizete Santana dos Santos, Paulinho Vogel ${ }^{*}$}

Pontifical Catholic University of Parana, (PUCPR), Curitiba, PR, Brasil

\begin{abstract}
The research work reported here aims to discuss the tensions that affect the identity configuration in the curricula in higher education, establishing dialogues among public policies, human rights and youth in the curriculum. The analysis, with an emphasis on human rights, contemplates reference of the policies allied to the arguments of Bobbio (2004); Candau et al. (2013), Eyng (2014) and Santos (2010), in dialogue with the students' perceptions from 15 higher education courses, situate the epistemological and contemporary contradictions that subsidize the reflection on the defining forces of the faces of curriculum. The results of the study allow us to highlight the ambiguous fragility of the insertion
\end{abstract}

AME: PhD in Education, e-mail: eyng.anamaria@gmail.com MSS: Master in Education, e-mail: marizete23@yahoo.com.br PV: Master in Education, e-mail: paulinhovogel@hotmail.com 
of human rights education in the curricula, given the overwhelming strength of the indexes. The inclusion of human rights education in the Course Projects is still very punctual, more satisfying the requirement of the legal requirement than expressing a pedagogical conception. In this scenario, higher education reinforces more exclusion, inequality by the values of competition and individualism than inclusion through dialogue with equality and the difference which constitute the diversity that supposes the exercise of the values of dignity and solidarity.

Keywords: Public Policies. Higher education. Identity. Curriculum. Right to education.

\section{Resumo}

O trabalho de investigação que relatamos tem como objetivo discutir as tensões que incidem na configuração identitária nos currículos na educação superior, estabelecendo diálogos entre as políticas públicas, os direitos humanos e as juventudes no currículo. A análise, com ênfase nos direitos humanos, contempla referenciais das políticas, argumentos de Bobbio (2004); Candau et al (2013), Eyng (2014) e Santos (2010), em diálogo com as percepções de estudantes de 15 cursos da educação superior, que situam as contradições epistemológicas e políticas contemporâneas que subsidiam a reflexão sobre as forças definidoras das faces do currículo. Os resultados do estudo permitem destacar a ambígua fragilidade da inserção da educação em direitos humanos nos currículos diante da esmagadora força dos índices. A inclusão da educação em direitos humanos nos Projetos de curso ainda é muito pontual, mais atende a exigência do requisito legal do que expressa uma concepção pedagógica. Nesse cenário, a educação superior mais reforça a exclusão, a desigualdade pelos valores da competição e do individualismo do que a inclusão via diálogo com a igualdade e a diferença que constituem a diversidade que supõe o exercício dos valores da dignidade e da solidariedade.

Palavras-chave: Políticas Públicas. Educação Superior. Identidade. Currículo. Direito à Educação. 


\section{Introduction $^{1}$}

Brazilian educational policies, aligned with the guidelines of the human rights, guarantees established in international declarations and conventions, provide for the inclusion of human rights education in the pedagogical projects of the courses in Higher Education. The intention of this perspective is the formation of the wholeness which supposes the cultivation of the values of the dignity and solidarity for the professional and citizen exercise. However, the quality indicators of the evaluation guidelines of these same courses are parameterized by the reductionist indexes of student performance in the national course exams. The contradiction in the legal guidelines distorts the intentions at stake in the course curricula. In this sense, the effectiveness of human rights education in higher education is questioned, considering the curricular interfaces.

The methodological path of the study covered the documental analysis of policies that allows to establish the dialogue on human rights education between the political and theoretical-conceptual arguments with the perceptions of higher education students. In this study we highlight the international documents: Universal Declaration of Human Rights (UN, 1948); The Education we want for the generation of bicentennials: Educational Goals 2021 (OEI, 2008); World Conference on Higher Education 2009: The New Dynamics of Higher Education and Research for Change and Social Development (UNESCO, 2009); World Program for Human Rights Education - Second phase (UNESCO, 2012). And the national documents: Federal Constitution (BRAZIL, 1988); Law of Guidelines and bases of National Education (BRAZIL, 1996); National Human Rights Education Plan (BRAZIL, 2007); National Curricular Guidelines for Human Rights Education (BRAZIL, 2012); National Education Plan 2014-2024 (BRAZIL, 2014). Bobbio (2004); Candau et al (2013), Eyng (2014) and Santos (2010), who situate contemporary epistemological

1 Work produced in the scope of productivity research project subsidized by CNPq - Public policies, human rights and youth: intercultural curriculum interfaces. 
contradictions, subsidize reflection on the defining forces of the school curriculum faces.

\section{The faces of the curriculum in International Human Rights policies}

The constitutive equality and difference of the diversity of subjects and contexts implied in the guarantee of rights in the educational space defy '[...] the recognition of the other as subject of law and social actor [...]' (CANDAU et al., 2013, p. 37), which emphasizes the need to listen to the subjects of the curriculum. Therefore, "recognition and appreciation of the knowledge of subalternized groups implies ethically and politically respect for the other, different, and their culture" (CANDAU et al., 2013, p. 37). Thus, the construction of other possible identities may enable human rights education in daily curricula. To enter into the analysis of such possibilities, we will begin with the policy perspective in the field of human rights.

At the international level, the human rights affirmed in the Declaration of 1948 have their references in documents (American, English and French) of the 1700s and reaffirm the principles of the French Revolution: freedom, fraternity and equality. They are designed from the perspective of Western culture, following the logic of hegemonic standardization, which has lasted about forty years. This verification questions the fact that "human rights are not universal in their application" (SANTOS, 2010, p. 442), since they require a conception based on "[...] a human rights policy radically different from the hegemonic liberal" (SANTOS, 2010, p. 443).

Gradually, the most recent documents highlight the need of overcoming inequalities, prejudices, and discrimination produced and reinforced by a liberal, hegemonic and monocultural perspective. Thus, human rights education must be carried out in an inclusive perspective, recognizing equality and differences in guaranteeing the right to human dignity. 
This direction recognizes "Higher Education as a public good is the responsibility of all investors, especially of the government" (UNESCO, 2009). And human rights education as a transversal process throughout the completion of the curriculum, extending to the professional exercise and citizenship in the daily life of higher education graduates. "Human rights education is a lifelong process which builds knowledge and skills, as well as attitudes and behaviors to promote and support human rights" (UNESCO, 2012). This is one of the perspectives of the challenges posed to the curriculum of Higher Education, within the scope of the pedagogical projects in the courses.

In order to achieve this challenge, the focus is on education, whose proposal is for human rights education, recognizing it as a fundamental part of the set of rights, including the right to education itself. In this context, human rights education is "[...] defined as a set of activities for education, formation and information dissemination, aimed at creating a universal culture of human rights" (UNESCO, 2012). Still conceived as an education that integrates knowledge, strategies to protect the attitudes and behaviors of respect for the rights of all and for all. "Human rights education promotes the attitudes and behavior necessary for human rights for all members of society to be respected" (UNESCO, 2012).

It is, therefore, the conception of an integral education which supposes wide knowledge, values, and abilities, contemplating the different areas of scholastic and cultural knowledge. This proposition "[...] not only provides knowledge about human rights and the mechanisms to protect them, but also transmits the necessary skills to promote, defend and apply human rights in people's daily lives" (UNESCO, 2012). But composed by tangible, measurable learning and subjective, intangible learning that cannot be measured, such as respect and solidarity in coexistence.

In this sense, we believe in the potential of education in human rights that has "[...] as a central objective the formation of life and coexistence in the daily exercise of Human Rights as a way of life and social, political, economic organization and cultural at the regional, national and planetary levels" (BRAZIL, 2012b). 
This perspective has become stronger each day since the democratization of the Brazilian State, which has produced, since the 1980s, a set of policies that assume and affirm human rights in education as a principle. We emphasize this observation in the Federal Constitution (BRAZIL, 1988), in the Law of Guidelines and Bases of National Education n. 9394/96 (BRAZIL, 1996), in the National Human Rights Education Plan (BRAZIL, 2007), in the National Guidelines for Human Rights Education (BRAZIL, 2012b).

The Federal Constitution defines education as a social right, based on the democratic principles of equality, freedom, pluralism of ideas and pedagogical conceptions, free public education, valuation of teaching professionals, democratic management of public education, and guarantee of quality standard. "Education, the right of all and the duty of the State and the family, will be promoted and encouraged with the collaboration of society, aiming at the full development of the person, their preparation for the exercise of citizenship and their qualification for work" (BRAZIL, 1988). The conception of Education assumed in the Law of Guidelines and Bases of 1996 goes in the same direction. "Education, duty of the family and the State, inspired by the principles of freedom and the ideals of human solidarity, aims at the students' full development, their preparation for the exercise of citizenship and their qualification for work"” (BRAZIL, 1996).

In order to do so, the curricular pathways have as their intentions "[...] a pedagogical action that is conscientious and liberating, focused on the respect and appreciation of diversity, on the concepts of sustainability and the formation of active citizenship" (BRAZIL, 2007). Thus, "[...] education has been understood as one of the fundamental mediations both for access to the historical legacy of Human Rights and for the understanding that the culture of Human Rights is one of the foundations for social change". In the scope of public policies, expressed gradually in Brazilian educational legislation, "[...] education is recognized as one of Human Rights and Education in Human Rights is a fundamental 
part of all these rights, including one's own Right to education" (BRAZIL, 2012a).

The National Education Plan (2014-2024) reaffirms the need to guarantee the right to education, overcoming the visible signs of violation of this right that has been perpetuated in the form of insufficient places, lack of access, insufficient conditions of stay, evasion, In addition to the poor results.

However, the challenge of achieving Human Rights Education is still capable of encompassing the recognition and struggle to guarantee "a set of civil, political, social, economic, cultural and environmental rights, be they individual, collective, transindividual or diffuse, refer to the need for equality and defense of human dignity" (BRAZIL, 2012b). For this purpose, there is a need to include, in the curricula, actions in the perspective of human rights "with the purpose of promoting education for change and social transformation" (BRAZIL, 2012b). To do so, curricular spaces are required, characterized by fundamental human rights principles: "I - human dignity; II - equal rights; III - recognition and appreciation for differences and diversities; IV - secularity of the State; V - democracy in education; VI - transversality, experience and globality; And VII - socioenvironmental sustainability" (BRAZIL, 2012b).

\section{The faces of the curriculum in the Higher Education students' perceptions}

The demand for guaranteeing the rights of children and adolescents nationally and internationally has widened, given the worsening of schooling and access to the opportunity of education and work of youth in the current scenario, both in Brazil and in several other countries which have identified this problem.

Among the ten paradoxes of the dilemmas faced by the youth, we relate three that refer to the guarantee of the right to education. 1 . greater access to education, but less access to employment; 2 . more access 
to information, but less access to power; 3. more expectations of autonomy, but fewer possibilities of materializing it (CEPAL-OIJ, 2004, p. 1718). These paradoxes are faced by the youth population on a global scale, considering the inclusion-exclusion dilemmas that afflict them.

Contemporary youths caught up in this social, economic and cultural scenario are confronted with multiple demands, among them are: the need to contribute to the support of their family, the lack of incentives to work, performance and the attainment of certain consumer objects that one wishes to obtain before finishing education (OEI, 2008).

However, this same youth is also concerned with the issues of outdated pedagogies, which constitute outdated curricula, without meaning and educational function, considering the multiple and complex demands of the contemporary context. There is a need to overcome the formative proposals based on traditional curricula in which:

[...] the rule is memory learning, lack of connection between learning and lived reality, absence of the basic elements of young culture: - music, computers, information networks, sport - among the contents of learning, and the perception of what has been learned is meaningless and does not deserve the effort required (OEI, 2008, p. 61).

Human rights education may be able to bring about change in the direction of a curriculum, "[...] in which the lives of young people are integrated and also there is meaning to their activities and aspirations, this would be an important element for a greater number of young people at high risk of abandonment remain in school longer" (OEI, 2008, p. 61).

Thus, new dialogues between policies and programs with youths are demanded, in the guarantee and fulfillment of their rights, among which is the guarantee of the right to education in the curriculum. For this, extensive diagnoses are required as subsidies that favor the guarantee of rights, justice and youth protagonism in intercultural educational processes.

With this purpose, we bring elements of students' perceptions of 15 Higher Education courses which were heard on rights, justice and 
coexistence, in two stages according to the Delphi Technique, this investigation procedure allows the dialogue between the knowledge of the subjects. The collection takes place in "without physical proximity between the participants and without the need for people to identify their propositions, thus avoiding influence and interference between those involved, allowing all to manifest themselves authentically and freely" (EYNG, 1995, p. 63). The listening of young people in Higher Education included 607 students in the first phase and 413 students in the second phase.

Regarding the traits that characterize the young people who participated in the research. Regarding the periods they attend: in the $1^{\text {st }}$ Phase there was participation of 339 (55.6\%) students of the $2^{\text {nd }}$ Period and 268 (44.2\%) students of the 6th Period, making a total of 607 participants. In the $2^{\text {nd }}$ Phase, 276 (66.8\%) of the $4^{\text {th }}$ Period and 137 (33.2\%) of the $8^{\text {th }}$ Period participated, totaling 413 students.

The identifications regarding age, sex and colo, were made only in the first phase. Thus, of the 607 participants, the following were distributed: 18 years or less 108 (17.8\%); 19 to 23 years old 292 (48.1\%); 24 to 28 years old 107 (17.6\%); 29 to 33 years 46 (7.6\%); 34 to 38 years 20 (3.3\%); 39 years and over 28 (4.6\%); No Response 6 (1.0\%). Regarding the Sex, Female 363 (59.8\%); Male 242 (39.9\%); No response 2 (0.3\%), Regarding perceived color declared White 460 (75.8\%); Black 18 (3.0\%); Brown 84 (13.8\%); Yellow 5 (0.8\%); Indigenous 0 (0.0\%); No response $30(6,6)$.

The students heard in both phases were addressed collectively, covering all the students present in the classroom on the scheduled days. At the time, those present were informed about the research and its objectives, and all received data collection materials (question form and consent form). The instruments were completed individually by those who so wished, by signing the free and informed consent form. At the end, all the materials distributed were collected, both from those who wished to participate and from those who declined and delivered them blank, without any distinction between these two groups. After the collection, the instruments were numbered, typed and systematized using 
the Sphinx Léxica software, being the categorization made with reference in the content analysis, according to Bardin (2000).

The answers obtained in the first phase were grouped and categorized giving rise to sixteen items:

1. Basic rights, essential for survival and healthy living $174(22,8)$;

2. Right as legal order, defined by law, by "government" 100 (13.1);

3 . Right as inherent to the human being $77(10,1) ; 4$. Right as moral normalization, duty $62(8,1) ; 5$. Right that gives protection, ensures individual and collective integrity 53 (7.0); 6 . Rights that everyone can exercise, enjoy - equality $39(5,1) ; 7$. Right as choice, option, freedom $36(4,7) ; 8$.

Right as a way of ensuring the people's integrity, of the human being 30 (3,9); 9. Right as justice, "intercultural" equality 27 (3,5); 10. Right as a means of ensuring coexistence, order in rel. Personal and collective 24 (3,2); 11. Right as guarantee of citizenship 23 (3.0); 12. Individual and collective rights $20(2,6) ; 13$. Right as a way to equal all $18(2,4)$; 14 . Right as personal, individual usufruct in society $17(2,2)$; 15. Right as social life 15 (2.0) 16. Diverse 48 (6.3) including the right to identity (EYNG, 2013).

The items of the form applied in the second phase of the research to the same groups of students were composed from these answers. In addition to the central idea, brief explanations of the meanings assigned by students to each category were included in the form, constituting a specie and collective discourse.

In the forms applied in the second phase, students were informed that this was a new stage of the previous research, continuing the research begun in the previous semester and in which their classes had participated. They were also informed about the opportunity to know and position themselves on the set of perceptions enunciated by the participants in the first phase. At that stage, students were initially asked to read and classify the various perceptions about Human Rights, considering the possibility of contributing to the realization of human rights in society. 
The analysis should be done according to the legend: E - Extremely; $\mathrm{M}$ Very; R - Reasonable; P - Little; N - None; NSA - Not applicable.

Subsequently, they were asked to choose among the alternatives to indicate which one best defines human rights, according to their perception. The students' positions indicate the best possibility of conception about human rights, in order of value:

Human inherent right - Human rights are universal envisaged to ensure human dignity. 119 (28.8);

Right to justice and equality - Human rights are the guarantee of justice and equality for all. 104 (25.2);

Basic / Fundamental Rights - Human rights are the essential rights to survival and healthy living. 40 (9.7);

Right of freedom - Human rights are the rights of choice and freedom of expression to all without repression. 36 (8.7);

Right to identity - Human right to enjoy and be respected in their individuality. 35 (8.5);

Right of protection - Human right is to have ensured the individual and collective integrity. 35 (8.5);

Right to social life - Human rights are the experience and coexistence among people in society. 27 (6.5);

Right of citizenship guarantee - Human right is the guarantee of democratic participation $9(2,2)$;

Right as legal order - Human rights are applications of the law. 6 (1.5); Right as moral standardization - Human rights are rules and moral norms that determine the people's conduct. 6 (1.5);

No response and others - 8 (2.0). (EYNG, 2013).

The dynamics of the adopted research procedure allowed the participants' reflection on their initial positions, producing new perceptions between the valorization manifested in the first and second phases. In the second phase, students were asked about how they perceive human rights in school. The answers obtained in the first phase were grouped and categorized giving rise to thirteen items: 
1. 1. Right to education, to learn, quality $114(14,5) ; 2$. Right to be respected 82 (10.5); 3 . Right to equal treatment, equality 79 (10.1); 4. Right to individual and collective protection $68(8,7) ; 5$. Determination, moral standardization $60(7,7) ; 6$. Right to question, if express $41(5,2) ; 7$. Right to perform roles $38(4,9) ; 8$. Right to differences $34(4,3) ; 9$. Right to live together $25(3,2) ; 10$. Right of access $23(2,9) ; 11$. Right to meet individual needs $23(2,9) ; 12$. The right to integrity 22 (2,8); 13. Diverse 129 (19.4). (EYNG, 2013).

The manifestations in the second phase indicate a small change in the participants' reflection on the different alternatives presented in the form, producing new perceptions. After considering how each alternative can contribute to the realization of human rights in school, students were asked to choose among the categories presented, indicating which of the alternatives best defines human rights in the school.

As a category, equality is still highly valued, which can translate a conservative and exclusive conception of human rights. On the other hand, the right to quality education is still highly valued.

Right to equality - Human right in school is equal treatment without distinction or discrimination. 86 (20.8\%);

Right to quality education - Human right at school is the guarantee to a quality education, teachers and adequate infrastructure. 68 (16.5\%);

Right to freedom of expression - Human right in the school is the right to question, express freely and participate in different activities. 36 (8.7\%);

Right to inclusion - Human right in the school is inclusion, considering the individual characteristics. 34 (8.2\%);

Right to difference - Human right in the school is the guarantee of respect to the individual characteristics that differentiate each one. 33 (8.0\%);

Right to protection - Human right in the school are those that protect, preserve and ensure individual and collective integrity. 29 (7.0\%);

Right to respect - Human right in the school is mutual respect among the participants in the school community. 26 (6.3\%); 
Right to integrity - Human right in the school is the guarantee of the integrity of the people in the school community. 21 (5.1\%);

Right to full development - Human right in the school is the guarantee of the student's full development. 20 (4.8\%); (EYNG, 2013).

Youth positions outline their beliefs about what they understand about the guarantee of human rights and show evidence of denouncing the denial and violation of human rights in society and in schools. In this group of students, the presence of appreciation and/or expectation about the right to be respected and the right to question, express themselves in the school, observed in manifestations that basic education students heard in previous research. Therefore, the same indications of violations of rights echo in these juvenile perceptions.

Youth perceptions bring many elements so that we can rethink the curricula and guide them in interdisciplinary conceptions of human rights education, capable of materializing a transversal collective work of intercultural dialogue. "The collective challenge of constructing intercultural conceptions and practices of human rights encompasses young people in formation as subjects of rights, interlocutors and recipients of curricular proposals" (EYNG, 2014, p. 190).

Regarding the field of curriculum, this is a crucial issue, to convert students effectively into subjects who construct in partnership, their formative itinerary, co-authors, protagonists of their professional development projects, being the undergraduation the initial and decisive step in this trajectory.

In this direction, we seek to listen to the students'perceptions about the curricula in which they are inserted. Thus, the third question asked for the students was whether the human rights theme was present in the curriculum of their courses, and they should answer first yes or no. At that time, affirmative answers were 494 (81.4\%), 103 (17\%) students answered negatively and 10 (1.7\%) did not respond to the question. In these responses, the perceptions in the first phase indicated a rather positive and naive view of the curricula of their respective courses. This was evidenced when most of them did not know how to answer the following 
question: if yes, indicate how the course has worked on it. Only 218 indicated a way that would be addressed, that is, 286 (47.12\%) of the participants did not know how to respond. Still, those who answered most of the indications were quite generic:

1. Specific topics in one or more subjects 70 (28.9\%); 2. Specific disciplines, disciplinary work 54 (22.3\%); 3. Principles applied to a discipline 38 (15.7\%); 3. "Transversal" approach, integrated work 22 (9.1); 4. Daily life, application in situations of professional practices 11 (4.6\%); 5. Diverse: Strategies, punctual actions; Orientation, application made by teachers of the course; Alternative work, Perspective of approach in future disciplines. 23 (9.5\%); 6. No response 24 (9.9). (EYNG, 2013).

From the answers obtained in this question, we adopted, in addition to the students' instructions, the guidelines of Resolution $\mathrm{n}$. $01 / 2012$, in which we find a contradiction, or rather a duplicity as to the insertion of education in human rights. Article 6 defines the transversal approach.

Human Rights Education, in a transversal way, should be considered in the construction of the Political-Pedagogical Projects (PPP); Of School Rules; Institutional Development Plans (IDPs); Of the Pedagogical Course Programs (PPP) of Higher Education Institutions; Teaching and learning materials; Model of teaching, research and extension; Management, as well as the different evaluation processes. (BRAZIL, 2012b, my italics).

While in this article transversality as the way to conceive and work on Human Rights Education, outlines a curricular perspective capable of dialoguing with contexts and especially with the subjects that signify them. In article 7 of the same resolution, in addition to reducing human rights education only to knowledge (ignoring values, attitudes and practices), it authorizes the most varied possibilities, including referring to traditional, content-oriented curricular options. 
The insertion of knowledge concerning Human Rights Education in the organization of the curricula of Basic Education and Higher Education may take place in the following ways: I - through transversality, through themes related to Human Rights and treaties interdisciplinarily; II - as a specific content of one of the disciplines already existing in the school curriculum; III - in a mixed way, that is, combining transversality and disciplinarity. Single paragraph. Other forms of insertion of Education in Human Rights may still be admitted in the curricular organization [...]. (BRAZIL, 2012b, my italics).

For this reason, the relevance of the discussion on how to integrate Human Rights Education into the curriculum becomes even more strategic, encompassing human rights conceptions, the right to education, and curriculum conceptions. In the systematization of the second phase form, we incorporate the forms provided in article seventh of the resolution to the forms indicated by the students in the first phase as to what they identify in their courses.

In this phase the participants highlight another order for the inclusion of Human Rights Education in the curriculum.

Integrated work - a "transversal" approach in all the subjects of the course through transversality, through themes related to Human Rights, Justice and Coexistence treated interdisciplinarily;

Application of principles - in professional situations and in formation; Daily living - coexistence in the course based on rights and justice; Alternate work - addressed in a mixed way, that is, combining transversality and disciplinarity;

Specific topics - addressed as a specific content of one or more subjects already in the course curriculum;

Disciplinary Work - approach to a specific discipline to be inserted in the curriculum (EYNG, 2013).

The responses of the second phase, which first highlight the interdisciplinary approach to human rights education in the curriculum, are particularly encouraging in order to gradually think and develop other 
possibilities for identifying a curriculum that engages intercultural dialogue. Thus, human rights education in the curricula of undergraduate courses can guide "[...] equality and difference in the intercultural dialogue of the different languages, knowledge and rationalities of teachers and students, in an inclusive and emancipatory pedagogical process" (EYNG, 2014, p. 206). In this direction, the guarantee of the right to education requires that the higher education school be constituted as a space, through which "the phenomena of inequality and exclusion can be better understood and overcome" (EYNG, 2014, p. 207).

\section{Findings - Final Considerations}

Human rights education in the curricula of undergraduate courses assumes the transversal work which includes a) knowledge; b) feeling-values, attitudes; c) do - actions, involved in affirming, protecting and guaranteeing rights in higher education. This is the line of proposals for national and international human rights policies.

However, the analysis indicates that the ideals expressed in the policies are very distant from contemporary realities that have sharpened the cadres of exclusion, inequalities. These findings are presented in the diagnoses that international organizations themselves disseminate.

The results of the study allow us to highlight traits which configure an ambiguous school, whose alignments to both democratic purposes and neoliberal purposes produce a schizophrenic identity, split between conflicting texts, discourses and practices. We highlight, from this context, the configuration of one of the faces of the school sculpted by the evaluation policies that act as determinant in school practices in which competitive, individualistic, hegemonic and performative processes are produced. This aspect has been strengthened in recent years because of the violation of the right to education. 
And the other face, still very fragile in many countries, including Brazil, which has been more in the field of political speeches and texts than in the field of effective guarantee practices. Therefore, Bobbio's (2004, p. 16) finding is current: "The fundamental problem with respect to human rights today is not so much to justify them as to protect them. It is a non-philosophical but political problem."

In this context, the challenge of Higher Education is maintained in guaranteeing the right to education, based on policies and programs that value and stimulate participatory, dialogical and intercultural principles and processes. These principles and processes define the identity of the school that brings about the education of wholeness and supposes the cultivation of aesthetic, cultural, political and ethical values; values of solidarity, justice and respect as conditions for guaranteeing the right to education. This school promotes emancipatory learning, built collectively and that constitutes, operationalizes and invigorates the principles and values of inclusive and intercultural education in primary and higher education schools that are in fact space for guaranteeing rights through dialogue with diversity. Thus, the guarantee of the right to education, in the initial and continuous formation, can initiate a real dialogue with the diversity of subjects, contexts, times, spaces, possibilities.

Keeping the challenges to live these values and to articulate the spaces of class, school, with the political, social and environmental issues of daily life, we are challenged to search for alternatives to overcome exclusion, poor income distribution, devaluation of life, the degradation of the environment and all forms of violence still so present in the contemporary world.

\section{References}

BARDIN, L. Análise de conteúdo. Lisboa: Edições 70, 2000.

BOBBIO, N. A era dos direitos. 7. reimpr. Rio de Janeiro: Elsevier, 2004. 
BRASIL. Constituição da República Federativa do Brasil. Diário Oficial da União, Brasília, ano CXXVI, n. 191-A, seção 1, p. 1, 05 de outubro de 1988. Disponível em: <http://www.planalto.gov.br/ccivil_03/constituicao/constituicaocompilado.htm>. Acesso em: 03 jul. 2017.

BRASIL. Lei n. 9.394, de 20 de dezembro de 1996. Estabelece as diretrizes e bases da educação nacional. Diário Oficial da União, Brasília, seção 1, p. 27833, 23 de dezembro de 1996. Disponível em: <http://www.planalto.gov.br/ccivil_03/leis/ L9394.htm>. Acesso em: 03 jul. 2017.

BRASIL. Lei n. 13.005 de 25 de junho de 2014. Aprova o Plano Nacional de Educação - PNE e dá outras providências. Diário Oficial da União, Brasília, seção 1, p. 1, edição extra, 26 de junho de 2014. Disponível em: <http://www.planalto.gov.br/CCIVIL03/Ato20112014/2014/Lei/L13005.htm>. Acesso em: 03 jul. 2017.

BRASIL. Parecer CNE/CP n. 8/2012. Diretrizes Nacionais para a Educação em Direitos Humanos. Diário Oficial da União, Brasília, seção 1, p. 33, 30 de maio de 2012a. Disponível em: <http://portal.mec.gov.br/index.php?option=com docman\&view=download\&alias=10389-pcp008-12-pdf\&category_slug=marco2012-pdf\&Itemid=30192 >. Acesso em: 03 jul. 2017.

BRASIL. Plano Nacional de Educação em Direitos Humanos. Brasília: Comitê Nacional de Educação, Secretaria Especial dos Direitos Humanos, Ministério da Educação, Ministério da Justiça, UNESCO. 2007. Disponível em: <http://portal. mec.gov.br/index.php?option=com_docman\&view=download\&alias=21 91-plano-nacional-pdf\&category_slug=dezembro-2009-pdf\&Itemid=30192>. Acesso em: 03 jul. 2017.

BRASIL. Resolução n. 1, de 30 de maio de 2012. Estabelece Diretrizes Nacionais para a Educação em Direitos Humanos. Diário Oficial da União, Brasília, n. 105, seção, 1, p. 48, 31 de maio de 2012b. Disponível em: <https://prograd.ufg.br/ up/90/o/rcp001_12.pdf>. Acesso em: 03 jul. 2017.

CANDAU, V. M. F., et al. Educação em direitos humanos e formação de professores(as). 1. ed. São Paulo: Cortez, 2013. 
CEPAL-OIJ. La juventud en Iberoamérica. Tendencias y urgencias. Segunda edición. Santiago de Chile: CEPAL, 2004. Disponível em: <http://repositorio.cepal.org/ bitstream/handle/11362/2785/S2004083_es.pdf;jsessionid=D9A01710034C32 AA4E2FFFB8AFD31E95? sequence=1>. Acesso em: 04 jul. 2017.

EYNG, A. M. A formação do homem no processo pedagógico e sua fundamentação ântropo-filosófica: um estudo de caso. 1995. Dissertação (Mestrado em Educação) -Pontifícia Universidade Católica do Paraná, Curitiba, 1995.

EYNG, A. M. Projeto de pesquisa: políticas públicas, direitos humanos, justiça e violências nas escolas, desenvolvida pelo Grupo de pesquisa: políticas públicas e formação de professores, PPGE/PUCPR, 2013.

EYNG, A. M. Direitos humanos, justiça e convivência nas escolas: traços da teorização e percepções juvenis em diálogo, p. 183-208. In: CALIMAN, Geraldo (Org.). Direitos humanos na pedagogia do amanhã, Brasília, Liber Livro, 2014.

OEI [Organização dos Estados Ibero-Americanos]. A Educação que queremos para a geração dos bicentenários: Metas Educativas 2021. Madrid: OEI, 2008. Disponível em: <www.oei.es/historico/metas2021/metas2021_portugues.pdf〉. Acesso em: 03 jul. 2017.

ONU [Organização das Nações Unidas]. Declaração Universal dos Direitos Humanos. Paris: Assembleia Geral da ONU, 1948.

SANTOS, B. S. A gramática do tempo: para uma nova cultura política. 3. ed. São Paulo: Cortez, 2010.

UNESCO [Organização das Nações Unidas para a Educação, a Ciência e a Cultura]. Conferência Mundial sobre Ensino Superior 2009: As Novas Dinâmicas do Ensino Superior e Pesquisas para a Mudança e o Desenvolvimento Social. Paris: UNESCO, 5 a 8 de julho de 2009. Disponível em: <http://portal.mec.gov.br/index.php?option=com_docman\&view=download\&alias=2722-cmes-unesco-comunicadofinal-paris-2009\&category_slug=janeiro-2010-pdf\&Itemid=30192 > . Acesso em: 03 jul. 2017. 
UNESCO [Organização das Nações Unidas para a Educação, a Ciência e a Cultura]. Plano de Ação: Programa Mundial para Educação em Direitos Humanos - Segunda fase. Brasília: UNESCO, 2012. Disponível em: <http://unesdoc.unesco.org/images/0021/002173/217350por.pdf >. Acesso em: 03 jul. 2017.

UNESCO [Organização das Nações Unidas para a Educação, a Ciência e a Cultura]. Plano de Ação: Programa Mundial para Educação em Direitos Humanos - Terceira fase. Brasília: UNESCO, 2015. Disponível em: <http://unesdoc.unesco.org/ images/0023/002329/232922POR.pdf〉. Acesso em: 03 jul. 2017.

Received: 06/19/2017

Recebido: 19/06/2017

Approved: 07/04/2017

Aprovado: 04/07/2017 